\title{
Ranchers feel pressure on environment
}

Washington. The Clinton administration last week began moves to impose higher fees and tighter environmental restrictions on ranchers grazing herds on public land. The step is the first to run counter to the centuryold practice of encouraging settlement in the West through land-use subsidies.

The White House removed increases in grazing and mining fees from Clinton's deficit-reduction plan last winter because several Western lawmakers had threatened to withhold their votes. With his economic package now through Congress, Clinton

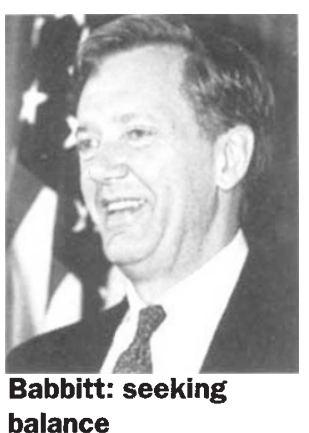

seems to be trying to dispel the notion that he renounced his environmental principles to buy votes: over the following months the administration will follow up its grazing laws with new regulations on

mining, timber and water rights.

Some 31,000 ranchers graze herds on the 272 million acres of federal lands administered by the Bureau of Land Management (BLM) and the Agriculture Department's Forest Service. Under the new plan, they would have to pay $\$ 4.28$ per animal unit (five sheep or a cow and calf) per month compared with $\$ 1.86$ now. This higher tariff would still be lower than the market rate $(\$ 5$ to $\$ 12$ ), but would nonetheless provide the Treasury with an extra $\$ 98$ million over the next three years.

"We've found a reasonable balance between the need to sustain the health of rangeland ecosystems and the need to sustain the economic health of rural Western areas," says Bruce Babbitt, Interior Secretary. Babbitt has championed the plan within the administration.

The 'Babbitt plan' would also curtail the use of pesticides, shorten grazing seasons and make renewal of rancher's leases dependent on their environmental record. And it would end a long-standing BLM policy that lets ranchers claim water rights and hold title to range improvements. The plan would also extend membership of BLM's grazing advisory boards to include not only ranchers, but also businesspeople, environmentalists and fish and wildlife experts; the boards help to review applications and set local standards for federal lands.

Conservationists have welcomed Babbitt's plan. They have long complained that the administration has done little to encourage environmental responsibility among commercial users of federal lands. Mismanaged grazing, they say, has caused compacting of soils, erosion and destruction of plant and animal diversity. Overgrazing in riparian areas, they say, has destroyed fisheries and nesting cover by creating muddy banks and stream runoff, while in desert areas it has threatened species such as the desert tortoise and Sonoran pronghorn by depleting water resources.

"They're running cow factories on land that belongs to all Americans," says Melanie Griffin, the public lands expert for the Sierra Club. "There's no reason why ranchers should be destroying the habitat and getting a free ride."

Ranching interests have denounced the

Babbitt plan. They claim it would deal a mortal economic blow to the livestock industry and to the small rural communities that depend on the ranching community. Industry experts reckon the plans could cause 20,000 ranching operations to close and increase beef prices by as much as a third.

The administration does not need approval from Congress to implement $\mathrm{Bab}$ bitt's plans. They will probably come into effect some time after 1994, after completing the lengthy federal rule-making process.

Susan Greene.

\section{Push for Gulf syndrome research}

Washington. US politicians and veterans' organizations are calling for more research into the effects of battlefield chemicals on health, because thousands of Gulf War veterans have developed a mysterious illness.

Researchers do not know what causes the multiple symptoms (see panel) reported by more than 6,000 US soldiers who served in the Gulf. "Chemical exposure is one of the clearest possibilities", says Terry Jemison, a

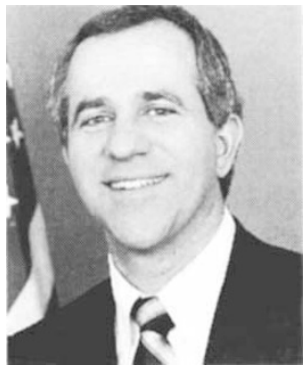

Buyer: diesel a factor spokesman for the US Veterans' Administration. But health officials at the US Department of Defense claim there is no epidemiological evidence for the so-called 'Gulf War syndrome'

Lack of consensus about

'multi-chemical sensitivity' is nothing new. The US health establishment has long questioned its existence because many feel the diagnostic and therapeutic approaches of clinical ecologists are inadequate.

"Until we develop a rational scientific approach to the problem, thousands of veterans will be caught in crossfire between doctors who consider chemical sensitivity to be real and doctors who don't," says Congressman Steve Buyer (Republican, Indiana). Buyer, who served in the Gulf, blames lead inhaled from a diesel-fuelled tent heater for a series of illnesses.

$\mathrm{He}$ and his colleagues in Congress will probably ask for funding for such research when they vote on the defence budget in the autumn. Congress has already authorized the Veterans' Administration and Department of Defense to grant $\$ 500,000$ annually for a review of scientific information on the effects of Gulf operations on health.

Claudia Miller, professor of allergy and immunology at the University of Texas
Health Science Center at San Antonio, is doing pioneering research in chemical sensitivity. She has planned a specialized environmental unit to isolate and blindly challenge veterans with chemicals. The direct challenge approach would be the "gold standard", she says, that would settle the debate. Miller estimates that the unit would cost \$1 million to build and $\$ 500,000$ a year to run.

Supporters of the veterans' cause applaud plans such as Miller's. They accuse the military of inertia and of being too ready to diagnose veterans with psychological problems such as post-traumatic stress disorder. The military responded slowly to reports of health problems caused by the use of the defoliant Agent Orange during the Vietnam War (see Nature 364, 373; 1993). It now reluctantly supports research on chemical sensitivity.

Nevertheless military officials claim that they can attribute only 30 of the 6,000 reported cases of Gulf-War-related illnesses to chemical exposure. If chemicals were found to cause widespread illness among troops the implications would be enormous. "Battlefields are full of chemicals", says Colonel Rick Erdtmann of the Army Surgeon General's Office. "I'm not sure how the military, or any industry, would function without them."

Susan Greene

\section{'Gulf War syndrome'}

Since returning from the Gulf thousands of veterans have complained of symptoms including fever, headache, loss of short-term memory, deteriorating vision, shortage of breath, coughing, diarrhoea, skin changes, bleeding gums, loss of hair and teeth, numbness,

tingling, aching joints and fatigue.

In the absence of any diagnosis, the condition has been dubbed 'Gulf War syndrome': a blanket term for one or several illnesses. S.G. 